\title{
HUKUM MENGULANG SHALAT DENGAN BERJAMA'AH (STUDI PEMAHAMAN HADIS MUKHTALIF)
}

\author{
Febriyeni \\ Fakultas Syariah IAIN Bukittinggi, febriyeni703@gmail.com \\ Beni Firdaus \\ Fakultas Syariah LAIN Bukittinggi, benifirdaus@gmail.com
}

\begin{tabular}{l|l|l} 
Diterima: 17 Juli 2018 & Direvisi : 10 November 2018 & Diterbitkan: 30 Desember 2018 \\
\hline
\end{tabular}

\begin{abstract}
I'adah (repeating prayer) is to repeat the implementation of an obligation in time according to the provisions of the sharak for the second time due to the occurrence of shortages or aging in the implementation of the first obligation. In the matter of repeating this prayer, the existence of the traditions of the Prophet Mubammad explained about the ability to repeat prayers in congregation, meaning someone who had prayed at his house, then he went to the mosque and found a congregation who would pray, he was allowed to repeat pray by joining the congregation. However, in other traditions, indications of probibition were found to repeat the same prayer on one day even with congregations. The two versions of the badith appear to be textually contradictory, but as Imam Shafi'i's statement states that the traditions of the Prophet Muhammad will not be contradictory, a solution can be found so that a proper understanding of the traditions that appear to be contradictory can be found. Therefore, it is necessary to analyze a complete understanding of the traditions of repeating prayers in congregation so that the law can be repeated in congregation.
\end{abstract}

Keywords: Hukum, Hadis, Mengulang Shalat, Berjama'ah

\begin{abstract}
Abstrak
I'adah (mengulang shalat) adalab mengulang pelaksanaan suatu kewajiban dalam waktunya menurut ketentuan syarak untuk kedua kalinya disebabkan terjadinya kekurangan atau uzur pada pelaksanaan kewajiban pertama. Dalam persoalan mengulang shalat ini, terdapatnya hadis-hadis Rasulullab $S A W$ yang menjelaskan tentang kebolehan mengulang shalat dengan berjamaah, maksudnya adalah seseorang yang telah melaksanakan shalat di rumahnya, lalu ia pergi ke mesjid dan mendapati suatu jamaah yang akan melaksanakan shalat, maka ia dibolehkan mengulang kembali shalatnya dengan ikut berjamaah. Namun pada hadis lain juga ditemukan indikasi larangan untuk mengulang kembali shalat yang sama pada satu hari sekalipun dengan berjamaah. Dua versi hadis tersebut tampak bertentangan secara tekstual, namun sebagaimana pernyataan Imam Syafi'i bahwa hadis-hadis Rasulullah SAW yang maqbul tidak akan ada yang saling bertentangan, melainkan dapat dicarikan solusi penyelesaiannya sehingga ditemukan pemahaman yang tepat terbadap hadis-badis yang tampak bertentangan. Oleh sebab itu, perlu dianalisis pemahaman yang utuh mengenai hadis-hadis mengulang shalat dengan berjamaah sehingga dapat diketabui bukum mengulang shalat dengan berjama'ah.
\end{abstract}

Kata Kunci: Hukum, Hadis, Mengulang Shalat, Berjama'ah

\section{PENDAHULUAN}

Dalam Islam, hadis merupakan sumber ajaran yang wajib diikuti. Hadis juga dijadikan sebagai hujjah atau landasan hukum dalam mengatasi berbagai persoalan umat, dengan ketentuan hadis tersebut dinilai maqbul. ${ }^{1}$ Namun timbul persoalan penting

1 Hadis maqbul adalah hadis yang kebenaran orang yang membawanya terbukti kuat, hukumnya wajib ketika hadis-hadis maqbul diangkat untuk dijadikan hujjah dalam menyelesaikan masalah yang dihadapi yaitu terdapatnya riwayatriwayat yang mukbtalif atau tampak saling bertentangan antara yang satu dengan yang

digunakan sebagai hujjah dan diamalkan. Syaikh Manna al-Qaththan, Pengantar Studi Ilmu Hadits, Judul asli: Mababits fi Ulum al-Hadits, Penerjemah Mifdhal Abdurrahman, (Jakarta Timur : Pustaka Al- Kautsar, 2008), Cet. Ke-3, h. 116. 
lainnya. Dengan kata lain, menyangkut masalah yang dihadapi tersebut di satu pihak ditemukan hadis-hadis dengan ketentuan hukum yang membolehkan, sedangkan di pihak lain ditemukan pula hadis-hadis dengan ketentuan hukum yang melarang.

$$
\text { Adanya hadis-hadis mukbtalif }
$$
menyangkut suatu masalah tertentu secara praktis dapat menimbulkan kebingungan dalam mengambil kepastian ajaran (ketentuan hukum) yang mengatur masalah tersebut, yang manakah di antaranya yang harus diikuti dan diamalkan seperti yang membolehkankah atau yang melarang, apabila cara-cara penyelesaian dari pertentangan-pertentangan yang tampak dari hadis- hadis itu tidak diketahui dengan baik. $^{2}$

Salah satu persoalan fikih yang mengandung hadis-hadis mukbtalif adalah I'adah shalat (mengulang shalat). Penjelasan lebih rinci diberikan oleh Mustafa al-Khin dan Musthafa al-Bugha dalam kitab al-Fiqh alManhaji 'ala Madæhabi Imam al-Syafi'i:

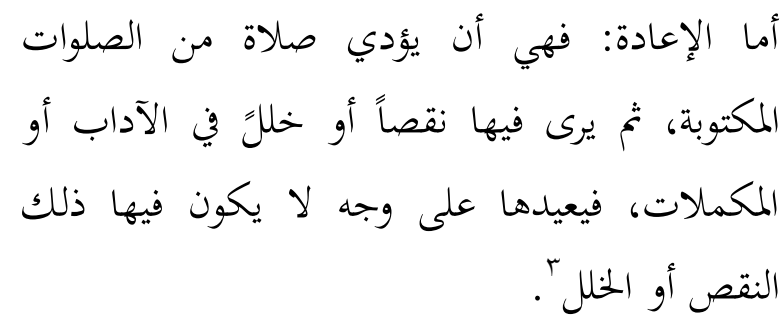

"Adapun i'âdah ialah ketika seseorang telah melaksanakan shalat fardhu, namun kemudian melihat ada cacat atau cela dalam kesempurnaan ataupun tata krama shalat, dan selanjutnya ia melaksanakan kembali shalat tersebut menurut tata cara yang tidak ada cela ataupun cacat."

Menurut ushul fikih, sebagaimana yang dikemukakan oleh Ibnu Hajib, tokoh usul fikih mazhab Maliki, i'adab adalah mengulang pelaksanaan suatu kewajiban dalam waktunya menurut ketentuan syarak untuk kedua kalinya

${ }^{2}$ Edi Safri, al-Imam al-Syafi'i : Metode Penyelesaian Hadis Mukhtalif, (Padang: IAIN IB Press, 1999), h. 4.

3 Mustafa al-Khin dan Musthafa al-Bugha dalam kitab al-Figh al-Manhaji 'ala Madzhabi Imam alSyafi'I, (Surabaya: Al-Fithrah, 2000), juz I, hal. 110 disebabkan terjadinya kekurangan atau uzur pada pelaksanaan kewajiban pertama. Misalnya, seseorang melaksanakan shalat, tetapi ia merasakan shalat yang dikerjakannya itu kekurangan salah satu rukun atau syarat shalat—seperti kentut ketika shalat—sehingga wudhunya batal. Lalu ia berwudhu kembali dan mengulangi shalatnya itu pada waktunya. Bisa juga pengulangan ini disebabkan keinginannya untuk mendapatkan pahala yang lebih banyak. Misalnya, seseorang telah melaksanakan shalat Dzuhur sendirian. Tetapi kemudian di tempat yang sama orang lain mengerjakan shalat berjamaah. Orang yang telah mengerjakan shalat sendirian itu boleh mengulangi shalat Dzuhurnya dengan ikut berjamaah. Pengulangan shalat Dzuhur ini pun disebut dengan i'adah.

Namun, setelah ditelusuri hadis-hadis tentang I'adah tersebut, terdapat riwayatriwayat yang bertentangan. Pada beberapa riwayat terdapat hadis-hadis yang membolehkan mengulang shalat dengan berjamaah. Hadis-hadis tersebut merupakan riwayat bil ma'na ${ }^{4}$. Dalam beberapa versi riwayat tersebut diceritakan bahwa Rasulullah SAW telah selesai menunaikan shalat secara berjamaah di mesjid. Lalu ia melihat dua orang laki-laki yang duduk di sudut mesjid sedangkan mereka tidak ikut shalat berjamaah bersama beliau. Maka Rasulullah SAW menanyakan apa penyebab mereka tidak ikut shalat berjamaah. Mereka menjawab bahwa mereka telah melaksanakan shalat di rumah. Lalu Rasulullah SAW bersabda : jika salah seorang dari kalian sudah melaksanakan shalat di rumah, kemudian menuju ke mesjid dan mendapati imam belum menunaikan shalat, maka shalatlah bersamanya karena shalat yang diulang itu akan menjadi pahala sunnah bagimu. Berikut ini kutipan hadisnya:

4 Riwayat bil ma'na adalah hadis dengan kandungan makna yang sama diungkapkan dengan lafaz yang berbeda. 
حَدَّتَنَا حَفْصُ بْنُ عُمَرَ حَدَّتَنَا شُعْبَةُ أَخْبَرَنِ يَعْلَى بْنُ

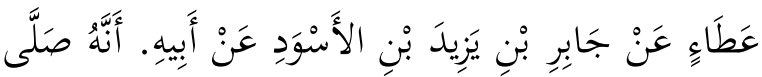

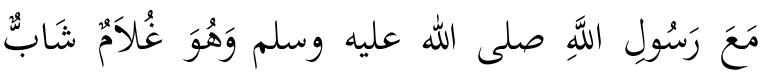

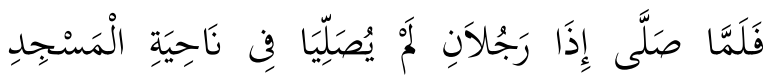

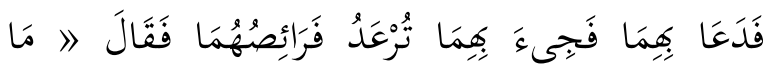

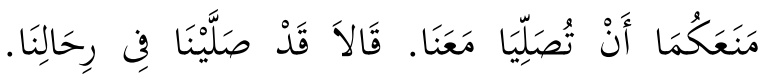

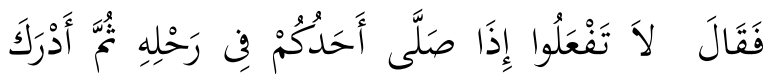

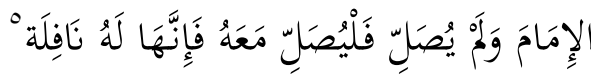

Meriwayatkan kepada kami Hafsh bin Umar, meriwayatkan kepada kami Syu'bah, mengabarkan kepadaku Ya'la bin 'Atha' dari Jabir bin Yazid bin al Aswad dari ayahnya bahwa dia telah selesai menunaikan shalat bersama Rasulullah SAW, kemudian ada dua orang yang tidak shalat di sudut mesjid, kemudian beliau memanggil kedua orang itu, dan mereka berdua datang (menghampirinya) dengan rasa takut. Maka Rasulullah SAW bertanya," Kenapa kalian berdua tidak shalat bersama kami?" Mereka menjawab,"Kami sudah melaksanakan shalat di rumah kami". Rasulullab $S A W$ bersabda, "Janganlah kalian lakukan itu, jika salah seorang di antara kalian ada yang sudah melaksanakan shalat di rumahnya, kemudian mendapati imam belum menunaikan shalat, maka shalatlah bersamanya, maka itu (shalat yang diulang) akan menjadi pahala sunnah bagimu.

Selain hadis di atas, ditemukan hadis lain yang juga membolehkan mengulang shalat dengan berjamaah, yaitu hadis yang diriwayatkan oleh Yazid bin Amir. Berikut ini hadisnya:

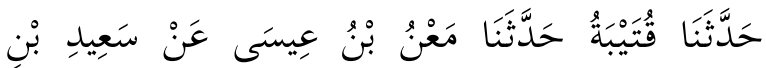

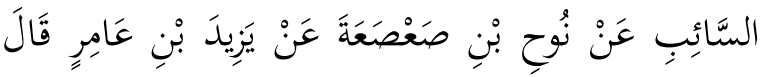

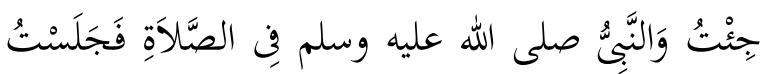

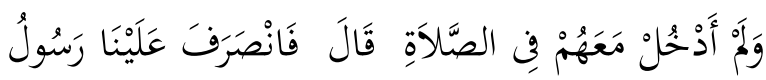

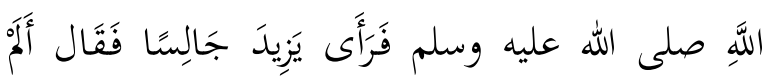

5 Imam Hafiz Abi Dawud Sulaiman bin al Ast'atsi al-Sajastani, Sunan Abi Dawud, (Beirut : Dar alKutub al-'Alamiyah, 2005), h. 105.

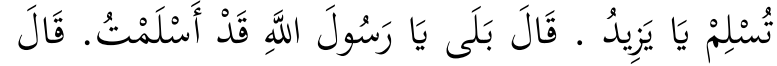

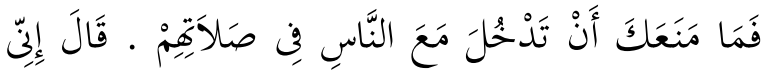

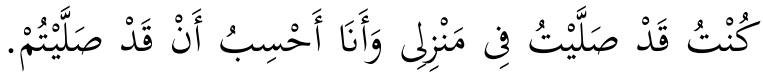

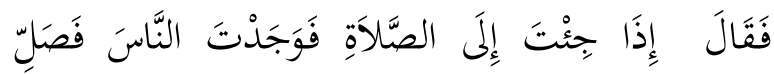

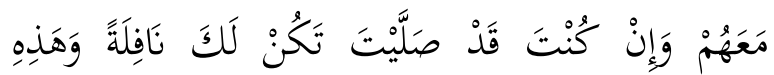
.

Meriwayatkan kepada kami Qutaibah, Meriwayatkan kepada kami Ma'in bin 'Isa dari Sa'id bin as Saib dari Nub bin Sha'shafi dari Yazid bin 'Amir berkata: Aku datang kepada Rasulullah $S A W$ saat beliau sedang shalat, sedangkean aku duduk dan tidak masuk bersama mereka. Maka Rasulullab SAW datang menghampiri dan bertanya, "Tidakkah kamu mengucapkan salam wahai Yarid?", Aku menjawab, "Ya, Wabai Rasulullab". Beliau berkata, "Apa yang menghalangimu tidak masuk bersama mereka untuk menunaikan shalat?" Aku menjawab, "Sesunggubnya aku telah melaksanakan shalat di rumabku, dan aku mengira bahwa kalian telah selesai melaksanakan shalat". Beliau bersabda, "jika kamu datang untuk shalat, kemudian kamu menemukan orang-orang sedang melaksanakan shalat, maka shalat kamu itu (shalat yang dikerjakan di rumah) menjadi sunnah. Dan ini (shalat kedua kalinya bersama imam) menjadi shalat wajib (fardhu)".

Hadis-hadis di atas dapat juga ditemukan dalam kitab Sunan al-Nasa'i, Sunan al-Tirmidzi, Musnad Imam Abmad bin Hanbal, Sunan al-Daraquthni, Mustadrake al-Hakim, Sunan al-Kubra karya al Baihaqi, dan alMushannaf karya Abdurrazaq. Di dalam kitab al-Jami' al-Shagir karangan Jalaluddin Abdurrahman bin Abi Bakr al-Suyuthi disebutkan bahwa hadis-hadis di atas berkualitas hasan, ${ }^{7}$ Imam al-Tirmidzi menilai hadis ini berkualitas hasan shabib. ${ }^{8}$

${ }^{6}$ Ibid.

7 Jalaluddin Abdurrahman bin Abi Bakr alSuyuthi (selanjutnya di tulis al-Suyuthi), al-Jami' alShagiir fi Ahaadits al-Basyiir al-Naziir, ( Indonesia : 
Secara tekstual dapat dipahami bahwa Rasululah SAW membolehkan untuk mengulang kembali shalat fardhu secara berjamaah meskipun sebelumnya ia telah melakukan shalat di rumahnya. Namun, dalam matan hadis tersebut tampak ada perbedaan, yaitu mengenai hukum shalat yang telah diulang tersebut. Dalam riwayat Yazid bin al Aswad mengatakan bahwa shalat yang diulang secara berjamaah itu menjadi shalat sunnah. Sedangkan dalam riwayat Yazid bin 'Amir mengatakan bahwa shalat yang diulang itu menjadi shalat fardhu. Ini menunjukkan adanya pertentangan dalam lafaz hadis. Untuk itu diperlukan penelitian dan pengkajian yang lebih dalam mengenai kualitas hadis-hadis tersebut, sehingga dapat diketahui mana hadis yang maqbul.

Persoalan selanjutnya adalah terdapat pula hadis-hadis yang secara tekstual melarang untuk melakukan shalat fardhu sebanyak dua kali sekalipun dengan berjamaah. Sebagaimana diceritakan dalam riwayat Sulaiman bahwa ia datang menemui Ibn Umar ke mesjid. Lalu ia mendapati Ibn Umar sedang duduk di lantai mesjid, padahal para sahabat yang lain sedang shalat berjamaah. Maka Sulaiman menanyakan penyebab Ibn Umar tidak ikut shalat berjamaah. Ibn Umar menjawab bahwa ia mendengar Rasulullah SAW bersabda:" Janganlah kalian melakukan shalat fardhu dalam sehari dua kali". Berikut ini kutipan hadisnya

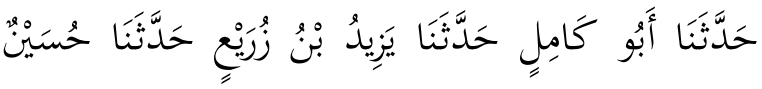

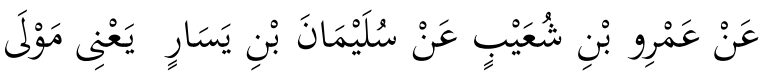

Maktabah Daar Ihya Al Kutub Al- 'Arabiyyah, t.th), h. 30.

8 Pernyataan al-Hafidh Ibnu Hajar yang disetujui oleh al-Suyuthi tentang hadis hasan shabih adalah sebagai berikut: a. Jika hadisnya mempunyai dua buah sanad atau lebih, maka berarti hadis tersebut adalah hasan menurut satu sanad, dan shabih menurut sanad lainnya, b. Jika hadisnya mempunyai satu sanad, maka berarti hadis tersebut adalah hasan menurut satu kelompok, dan shabih menurut kelompok lainnya.

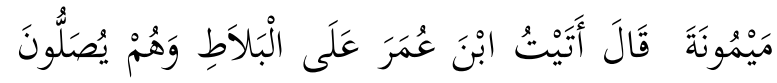

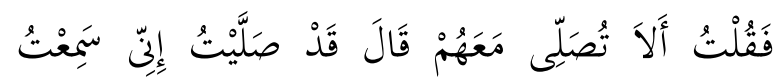

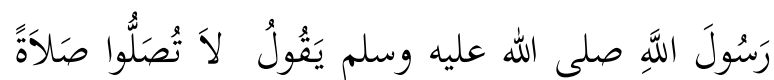

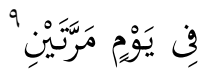

Meriwayatkan kepada kami Abu Kamil, meriwayatkan kepada kami Yazid bin Zurai, meriwayatkan kepada kami Husain dari Amru bin Syaibah, dari Sulaiman hamba sahaya Maimunah, ia berkata: Aku mendatangi Ibn Umar dan ketika itu dia sedang berada di atas lantai, sementara mereka sedang shalat. Kemudian aku bertanya kepadanya,"Apakah kamu tidak shalat bersama mereka? Dia menjawab aku telah shalat, sesunggubnya aku mendengar Rasulullab $S A W$ bersabda: Janganlah kalian melakukan shalat ( fardhu) dalam satu hari sebanyak dua kali.

Dalam Musnad Imam Ahmad bin Hanbal juga ditemukan riwayat tersebut. Berikut ini hadisnya:

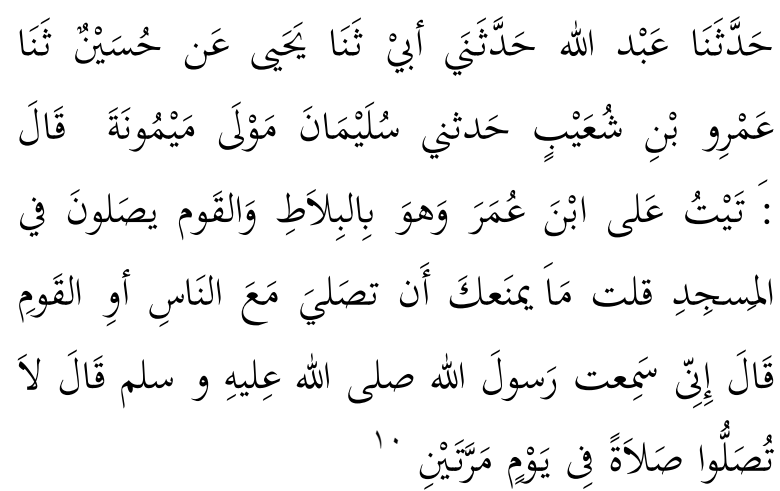

Meriwayatkan kepada kami Abdullah, meriwayatkan kepadaku ayabku meriwayatkan kepada kami Yabya dari Husain meriwayatkan kepada kami Amru bin Syua'ib meriwayatkan kepadaku Sulaiman hamba sabaya Maimunah, ia berkata: Aku mendatangi Ibn Umar dan ketika itu dia sedang berada di atas lantai, sementara orangorang sedang shalat di mesjid. Kemudian aku bertanya kepadanya," Apa yang menghalangimu untuk shalat bersama mereka?" Dia menjawab, "Sesungguhnya aku mendengar Rasulullab SAW bersabda: Janganlah kalian melakukan shalat (wajib) dalam satu bari sebanyak dua kali".

9 Abi Dawud. op. cit., h. 105.

10 Ahmad bin Hanbal, Musnad Ahmad Bin Hanbal, (Beirut: Dar al Fikr, t. th.), Juz 9, h. 496. 
Hadis-hadis yang senada dengan hal di atas, juga ditemukan dalam Sunan alDaruquthni, Shabih Ibn Khuzaimah, Musnad Imam Ahmad bin Hanbal, Tarikh al-Kabir karya al Bukhari, Sunan al-Kubra karya al Baihaqi, dan Syarah al-Sunnah karya al Baghawi. Di dalam kitab al-Jami' al-Shagir disebutkan bahwa hadishadis di atas berkualitas hasan. ${ }^{11}$

Dengan demikian diketahui bahwa kualitas hadis-hadis tersebut adalah hasan, sehingga dapat dikategorikan sebagai hadis maqbul. Di samping itu, secara tekstual hadishadis tersebut mengandung pertentangan (mukbtalif). Dalam beberapa riwayat ditemukan indikasi kebolehan mengulang shalat dengan berjamaah, namun mengenai hukum shalat yang diulang itu terdapat dua versi matan yang berbeda. Sedangkan di dalam riwayat lain juga ditemukan indikasi larangan mengulang shalat dengan berjamaah.

Berdasarkan pemaparan di atas, penulis merasa tertarik untuk meneliti dan mengkaji secara komprehensif tentang bagaimana pemahaman yang utuh mengenai hadis-hadis mengulang shalat dengan berjamaah dengan mencarikan solusi yang tepat dalam menyelesaikan pertentangan hadishadis tersebut. Sehingga dapat diketahui hukum mengulang shalat dengan berjama'ah.

\section{METODE PENELITIAN}

Dalam pembahasan jurnal ini, penulis menggunakan jenis penelitian library research, yaitu penelitian dengan mengumpulkan datadata dan menelaah buku atau literatur perpustakaan yang terkait dengan topik yang dibahas. Karena studi ini menyangkut hadis dan persoalan fiqh, maka sumber primernya adalah kitab-kitab hadis yang mu'tabar yang didalamnya memuat hadis ini. Di antara kitabkitab tersebut adalah Sunan al-Tirmidzi, Sunan al-Nasa'i, Sunan Abi Dawud, Musnad Imam

11 Al-Suyuthi, op. cit., h. 201.
Abmad bin Hanbal, Subulussalam dan Nailul Authar, serta dilengkapi dengan kitab-kitab syarah hadis yang dianggap representatif yaitu Tubfath al-Ahwazi bi Syarbi Jami' Tirmidri, Syarah Sunan al-Nasa'i li Suyuthi, 'Aun al-Ma'bud Syarah Sunan Abi Dawud, dan kitab fiqh lain yang terkait.

Adapun dalam memahami hadis mukbtalif, penulis menggunakan metode aljam'u wa al-tawfiq, yaitu penyelesaian hadishadis mukhtalif dari pertentangan yang tampak (makna lahiriahmya) dengan cara menelusuri titik temu kandungan makna masingmasingnya sehingga maksud sebenarnya yang dituju oleh yang satu dengan yang lainnya dapat dikompromikan. Sedangkan pendekatan yang dipakai adalah pendekatan tematis korelatif.

\section{STUDI TAKHRIJ HADIS TENTANG KEBOLEHAN MENGULANG SHALAT DENGAN BERJAMA'AH}

Untuk melacak hadis-hadis tentang kebolehan mengulang shalat dengan berjamaah penulis menggunakan kitab alMu'jam al-Mufahras li Alfazh al-Hadis alNabawiyah karya Arnold J. Wensink. Berdasarkan penelusuran dari kitab tersebut diperoleh informasi bahwa hadis tentang kebolehan mengulang shalat dengan berjama'ah terdapat di dalam Sunan Abi Dawnd kitab Shalat bab 56, juga ditemukan dalam Sunan al-Tirmidri kitab Shalat bab 49, Sunan alNasa'i kitab Imamah bab 54, Sunan al-Darimi kitab Shalat bab 94 dan dalam Musnad Imam Ahmad bin Hanbal Jilid 2 halaman 161. Berikut kutipan hadis yang terdapat dalam Sunan Abi Dawud, Kitab Shalat bab 56, riwayat dari Yazid bin al-Aswad

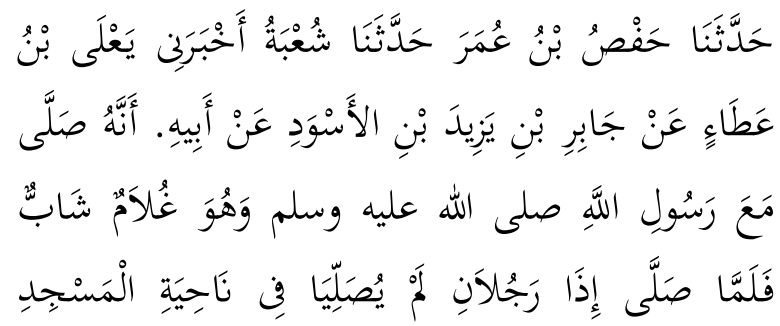




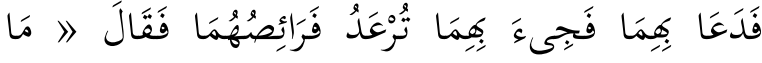

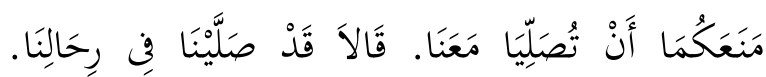

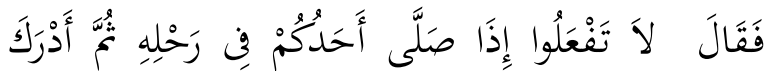

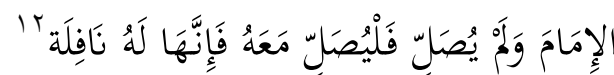

Meriwayatkan kepada kami Hafsh bin Umar, meriwayatkan kepada kami Syu'bah, mengabarkan kepadaku Ya'la bin 'Atha' dari Jabir bin Yazid bin al-Aswad dari ayahnya bahwa dia telab selesai menunaikan shalat bersama Rasulullab $S A W$, kemudian ada dua orang yang tidak shalat di sudut mesjid, kemudian beliau memanggil kedua orang itu, dan mereka berdua datang (menghampirinya) dengan rasa takut. Maka Rasulullah SAW bertanya," Kenapa kalian berdua tidak shalat bersama kami?"Mereka menjawab,"Kami sudab melaksanakan shalat di rumah kami". Rasulullah $S A W$ bersabda, "Janganlah kalian lakukan itu, jika salab seorang di antara kalian ada yang sudah melaksanakan shalat di rumahnya, kemudian mendapati imam belum menunaikan shalat, maka shalatlah bersamanya, maka itu akan menjadi pabala sunnab baginya.

Berdasarkan kutipan hadis di atas dapat diketahui bahwa terdapat enam orang perawi yang meriwayatkan hadis ini. Pada tingkat sahabat, hadis ini diriwayatkan dari Yazid bin al-Aswad, Setelah itu Jabir bin Yazid bin Al-Aswad, Ya'la bin Atha', Syu'bah, Hafsh bin Umar dan Abu Daud. Dalam matan hadis diceritakan tentang dua orang laki- laki yang tidak ikut shalat bersama Rasulullah SAW disebabkan karena mereka telah mengerjakan shalat di rumah. Namun hal ini tidak disukai oleh Rasul, sehingga mereka dipanggil dan mereka menghampiri Rasul dengan rasa takut. Maka Rasulullah SAW menyeru agar mereka mengulang kembali shalatnya jika menemukan suatu jamaah, karena shalat yang diulang itu menjadi pahala sunnah baginya.

Untuk mengetahui kualitas hadis-hadis tentang kebolehan mengulang shalat dengan

12 Imam Hafiz Abi Dawud Sulaiman bin alAsts'ats al-Sajastani, Sunan Abi Dawud, (Beirut : Dar alKutub al-'Alamiyah, 2005), h. 105. berjamaah, berikut ini penulis kemukakan kritik sanad dan matan dari hadis tersebut. Dilihat dari sanad hadis yang ada pada jalur Abi Dawud, semua periwayatnya bersambung mulai dari mukharij sampai ke Rasul. Para perawi juga mendapatkan penilaian ta'dil dari para ulama, dan tidak ada satupun yang terkena jarh. Namun ada seorang perawi yang dinilai kurang dhabith, yaitu Syu'bah bin alHajaj. Sedangkan dilihat matan hadis, mempunyai kesamaan dengan matan dalam periwayatan lain. Meskipun ada perbedaan dalam segi pengucapan (lafal), namun memiliki kesamaan dalam hal makna hadis, sehingga dapat dipahami bahwa hadis ini adalah riwayat bil ma'na. Adanya kesamaan dalam makna matan hadis ini menambah kuat dugaan bahwa matan hadis ini shabih. Dalam meneliti kandungan matan hadis, penulis lihat dari kitab 'Aun al-Ma'bud syarah kitab Sunan Abi Danud, Tubfath al-Ahwari syarah kitab Sunan alTirmidri, Nailul Authar dan Subul al-salam yang berfungsi sebagai penjelas dari maksud hadis. Berdasarkan hal ini, penulis melihat bahwa kandungan matan hadis ini tidak mengandung pertentangan dengan Al-Qur'an. Berdasarkan kritik sanad dan matan di atas, penulis menyimpulkan bahwa hadis tentang kebolehan mengulang shalat dengan berjamaah berdasarkan riwayat Abi Dawud, melalui jalur Yazid bin al-Aswad adalah hadis yang makbul berkualitas hasan, karena ada perawi yang dinilai kurang dhabith.

Takhrij Hadis -Hadis Tentang Larangan Mengulang Shalat Dengan Berjama'ah

Hadis ini ditemukan dalam Sunan Abi Dawnd, tercantum dalam kitab Shalat bab 5V dan Musnad Ahmad bin Hanbal, Jilid 2, halaman 19. Berikut kutipan hadis yang terdapat dalam Sunan Abi Dawnd, Kitab Shalat bab 57

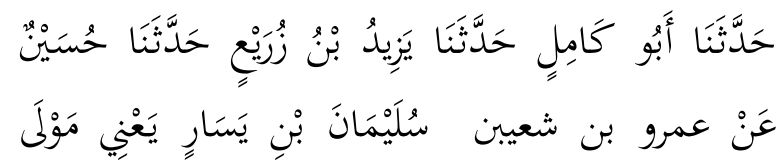




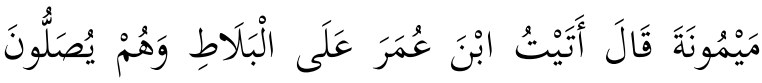

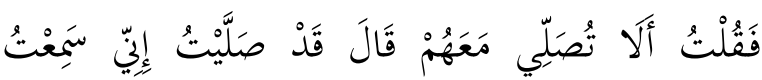

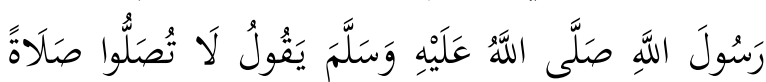

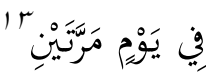

Meriwayatkan Abu Kamil, meriwayatkan kepada kami Yazid bin Zurai', meriwayatkan kepada kami Husain dari Amru bin Syaibab, dari Sulaiman bamba sabaya Maimunah, ia berkata: Aku mendatangi Ibn Umar dan ketika itu dia sedang berada di atas lantai, sementara mereka sedang shalat. Kemudian aku bertanya kepadanya," kamu tidak shalat bersama mereka? Dia menjawab aku telah shalat, sesunggubnya aku mendengar Rasulullab $S A W$ bersabda: Janganlab kalian melakukan shalat (wajib) dalam satu bari sebanyak. dua kali.

Hadis di atas diriwayatkan oleh tujuh orang perawi hadis yaitu Ibn Umar, Sulaiman bin Yasr, Amr bin Syu'aib, Husain, Yazid bin Zurai', Abu Kami, dan Abu Daud. Dalam matan hadis diketahui bahwa Sulaiman mendatangi Ibn Umar, ia melihat Ibn Umar duduk di lantai sedangkan sahabat yang lain sedang shalat. Lalu Sulaiman menanyakan perihal Ibn Umar tidak ikut shalat bersama mereka, dan Ibn Umar menjawab bahwa ia telah shalat, lalu ia membacakan Sabda Rasulullah SAW : Janganlah kalian melakukan shalat (wajib) dalam satu hari sebanyak dua kali.

Pada hadis ini secara tekstual dapat dipahami bahwa dilarang untuk mengulang kembali shalat, sekalipun pengulangannya itu dalam konteks berjamaah. Karena lafaz hadis dalam bentuk nahy ( larangan). Dilihat dari sanad hadis yang ada pada jalur Abi Dawud, semua jalur sanad-nya bersambung mulai dari mukharij sampai ke Rasul. Para perawi juga mendapatkan penilaian ta'dil dari para ulama, mengenai Amru bin Syu'aib, penulis berpendapat bahwa ia adalah seorang yang 'adil, namun kurang dari segi ke-dhabith-annya. Hal ini terlihat dari penilaian ulama terhadapnya, Jadi dapat disimpulkan bahwa sanadnya adalah basan. Riwayat basan merupakan riwayat maqbul yang dapat dijadikan hujjah. Karena sanad hadis di atas maqbul maka sangat kuat dugaan bahwa matannya pun maqbul dapat dijadikan hujjah.

Dalam meneliti susunan lafal hadis, penulis melihat bahwa pada matan hadis yang ada pada jalur Abi Dawud mempunyai kesamaan dengan matan dalam periwayatan Ahmad bin Hanbal, meskipun ada perbedaan dalam segi pengucapan (lafal), namun memiliki kesamaan dalam hal makna hadis, sehingga dapat dipahami bahwa hadis ini adalah riwayat bil ma'na. Adanya kesamaan dalam makna matan hadis ini menambah kuat dugaan bahwa matan hadis ini maqbul dan dapat dijadikan hujjah. Berdasarkan kritik sanad dan matan di atas, penulis menyimpulkan bahwa hadis tentang larangan mengulang shalat dengan berjamaah berdasarkan riwayat Abi Dawud merupakan hadis maqbul yang memiliki kualitas hasan dan dapat dijadikan sebagai hujjah.

\section{PENYELESAIAN PERTENTANGAN HADIS MENGULANG SHALAT DENGAN BERJAMA'AH MENGGUNAKAN METODE $J A M ' U$ WA AT-TAUFIQ}

Dua hadis yang maqbul apabila terlihat bertentangan secara lafaznya, maka diperlukan pemahaman yang tepat terhadap kedua hadis tersebut, sehingga dapat diperoleh penyelesaian yang tepat dalam penyelesaian pertentangan kedua hadis itu

Untuk mendapatkan pemahaman yang tepat terhadap hadis-hadis tentang mengulang shalat dengan berjamaah, terlebih dahulu penulis akan mengemukakan pendapat dari ulama hadis.

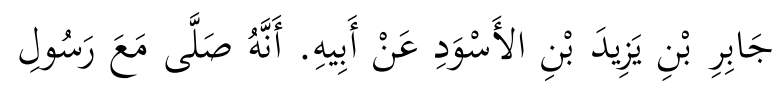

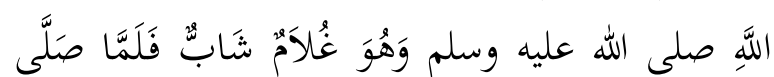

13 Abi Dawud, loc.cit. 


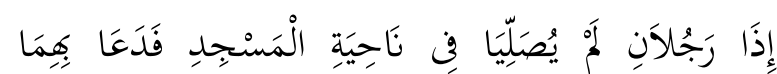

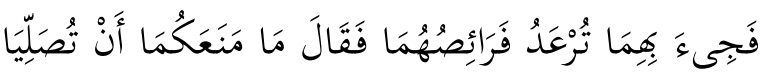

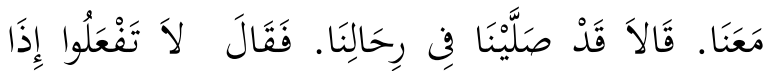

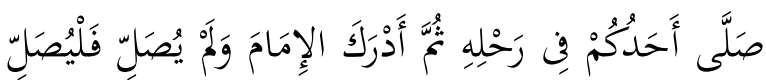

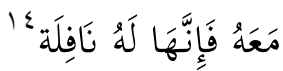

Jabir bin Yazid bin al-Aswad dari ayahnya babwa dia telab selesai menunaikan shalat bersama Rasulullah $S A W$, kemudian ada dua orang yang tidak shalat di sudut mesjid, kemudian beliau memanggil kedua orang itu, dan mereka berdua datang (menghampirinya) dengan rasa takut. Maka Rasulullah SAW bertanya," Kenapa kalian berdua tidak shalat bersama kami?" Mereka menjawab,"Kami sudah melaksanakan shalat di rumah kami". Rasulullah SAW bersabda, " Janganlah kalian lakukan itu, jikea salab seorang di antara kalian ada yang sudah melaksanakan shalat di rumahnya, kemudian mendapati imam belum menunaikan shalat, maka shalatlah bersamanya, maka itu akan menjadi pabala sunnab baginya.

Kata lam yushalliya maksudnya adalah tidak ikut shalat bersama Nabi SAW, Kata tur'adu merupakan bentuk pasif dari kata ar'ada artinya adalah gemetar, yakni bergoyang dan mengginggil karena takut. Kata faraishuma, berasal dari kata faraish, yaitu bentuk jamak taksir dari kata farishah. Sedangkan al farishah adalah bentuk tunggal dari al fairish yaitu uraturat leher. Al Farishah adalah sebuah daging antara punggung dengan pundak yang terus bergemetar yaitu bergoyang karena takut. Maknanya adalah kedua orang tersebut ketakutan terhadap Rasulullah. fii ribalina maksudnya adalah di rumah kami, kediaman kami, kata itu jamak dari kata rabli dan yang dimaksud adalah manzil, yaitu rumah. Kata laa taf'aluu artinya janganlah kamu berbuat demikian untuk yang kedua kalinya. Kata Fashalli ma'abu artinya shalatlah bersama mereka, yakni bersama jamaah mesjid itu. Kata

${ }^{14}$ Imam Hafiz Abi Dawud Sulaiman bin alAts'ats al-Sajastani, Sunan Abi Dawud, (Beirut : Dar al Kutub al-Alamiyah, 2005), h. 105. fainnaha labu nafilah artinya maka shalat itu bagi kamu berdua menjadi shalat sunnah. Di dalamnya terkandung penjelasan, bahwa shalat yang kedua kalinya dalam pengulangan itu menjadi shalat sunnah. ${ }^{15}$

Di dalam redaksi hadis ini dijelaskan secara implisit mengenai kodisi latar historis asbab al-wurud hadis yaitu ketika Yazid bin alAswad ikut shalat bersama Nabi sedang waktu itu ia masih remaja, ketika beliau selesai shalat tiba-tiba ada dua orang tidak ikut shalat di sudut mesjid, lalu keduanya di panggil, ... hingga akhir hadis.

Dan dalam lafaz al-Tirmidzi, disebutkan saya telah ikut serta bersama Nabi menunaikan haji wada', lalu melakukan shalat Subuh bersama Nabi SAW di Mesjid Khaif, yaitu mesjid yang terkenal di Mina. Al- Thibi mengatakan bahwa alasan penamaannya al Khaif adalah karena al-Khaif itu suatu wilayah yang keadaannya lebih rendah dari kaki bukit dan lebih tinggi dari parit (saluran air). ${ }^{16}$

Setelah Nabi Muhammad SAW selesai shalat, yakni "setelah menunaikan shalat dan membaca salam", secara lahiriahnya beliau menjadikan bagian muka yang sebelah kanannya diarahkan ke arah makmum dan bagian muka sebelah kirinya diarahkan kearah kiblat. Maka ketika itu Rasulullah SAW melihat dua orang laki-laki yang tidak ikut shalat bersamanya. Lalu Rasul meminta agar kedua orang itu dibawa dan hadirkan ke hadapannya. Kedua orang tersebut kelihatan ketakutan terhadap Rasulullah SAW. Maka Nabi menanyakan alasan mengapa mereka tidak ikut shalat berjamaah, mereka menjawab karena mereka telah menunaikan shalat di rumah.

15 Abu Alula Muhammad Abdurrahman bin Abdurrahman al Mubarakfuri, Tuhfatul Abwadziy Syarah Sunan al- Tirmidziy, Penerjemah Shafaul Qalbi ( Jakarta: Pustaka Azzam, 2008), h. 439 selanjutnya di baca al Mubarakfuri

${ }^{16}$ Abdul Qadir Syaibah al Hamd, Fiqhul Islam Syarah Bulughul Maram, judul asli: Fiqhul Islam Syarah Bulughul Maram min jami' adillatil abkam, Penerjemah, Muhammad Iqbal, (Jakarta: Dar al-Haq, 2005), jilid 2, h. 115. 
Lalu Rasulullah pun bersabda: Jika kamu telah shalat di rumah, kemudian datang ke Mesjid ada suatu jamaah, lalu kamu shalatlah bersama mereka maka shalat itu bagi kamu menjadi shalat sunnah.

Di dalam kedua hadis ini terkandung pengertian, bahwa siapa yang telah selesai shalat, lalu menghadiri shalat berjamaah dengan yang lain, maka disunatkan baginya untuk shalat kembali bersama dengan mereka dengan niat sebagai amal tambahan baginya (nafilab). Hal ini dikatakan oleh al-Hasan, alZuhri, Imam al-Syafi'i, Imam Ahmad dan Imam Ishaq. Sedangkan kalangan mazhab Hanafi dan Maliki mengatakan, bahwa orang yang bersangkutan tidak boleh lagi mengulangi shalatnya, terkecuali apabila ia mengerjakan shalat pertamanya hanya sendirian.

Menurut al-Khattabi: Shalat yang kedua ini, dinamakan shalat itsar dan ikbtiar (yakni shalat yang dilakukan atas kemauan orang yang ingin shalat itu sendiri), bukan shalat yang memiliki sebab untuk diulangi, seperti orang yang mendapati jamaah yang sedang shalat, maka dia ikut shalat lagi bersama jamaah itu, untuk memperoleh fadhilah jamaah. ${ }^{17}$

Abd al-Barr berkata, "Mayoritas ahli fikih berkata: Adapun orang yang dianjurkan mengulang shalat bersama imam dengan berjamaah hanya orang yang shalat sendirian di rumahnya atau di luar rumahnya. Sedangkan orang yang shalat dalam suatu jamaah meskipun sedikit, maka ia tidak dianjurkan mengulanginya pada jamaah yang lebih banyak. Karena, jika ia dianjurkan untuk mengulanginya pada jamaah yang lain, maka ia pun akan dianjurkan mengulanginya pada shalat yang ketiga dan keempat hingga tiada batas akhirnya dan kerusakannya tidak dapat diragukan lagi. Inilah pendapat dari Malik, Abu Hanifah, dan sahabat-sahabat mereka. Dalil

17 Teungku Muhammad Hasbi al- Siddiqiy, Koleksi Hadis-hadis Hukum 4, ( Jakarta: Yayasan Teungku Hasbi al- siddiqiy, 1994, h.87 mereka adalah hadis yang melarang mengulang shalat fardhu ( yang sama) dua kali dalam satu hari. Sebagimana hadis riwayat Ibn Umar

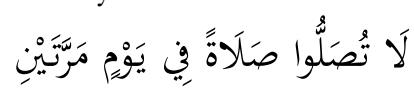

Janganlah kalian melakukan shalat (wajib) dalam satu hari sebanyak dua kali.

Menurut Ahmad, Daud, dan Kelompok Zhahir, berpendapat bahwa shalat itu diulang kembali. Alasannya adalah hadis dari Yazid bin al-Aswad. Dalam redaksi hadis terlihat jelas bahwa Nabi menyuruh untuk kembali shalat, walupun telah melaksanakan shalat sebelumnya. Zhahir hadis mengharuskan pengulangan shalat bagi seseorang yang datang ke Mesjid. Sebab, hadis ini mempunyai kekuatan sebagai dalil secara umum, kebanyakan ulama berpendapat bahwa jika dalil umum didatangkan dalam sebuah kasus yang khusus, maka dalil tersebut tidak dipahami sebatas permasalahan itu saja.

Menurut Ibn Qudamah, siapa yang mengerjakan shalat fardhu, kemudian dia mendapatkan shalat itu lagi dalam suatu jamaah, maka lebih baik jika dia mengulang kembali shalatnya, kalau pada waktu itu dia berada di mesjid yang jamaahnya sedang menunaikan shalat. baik dia telah menunaikan shalatnya sendirian di rumah ataupun telah melakukan jamaah sebelumnya, baik beserta imam di kampungnya atau bukan.

Menurut hikayat al-Astram dan alKhiraqi, al-Qhadi berkata; Jika dia shalat bersama imam di kampungnya, maka lebih baik dia mengulangi shalatnya. Namun jika mendapati bukan imam kampungnya, maka hendaklah dia mengulangi yang selain shalat shubuh dan Ashar. ${ }^{18}$

Ibn Abd al-Barr dalam al-Istidzkar berkata: "Ahmad bin Hanbal, Ishaq bin Rahawaih, Menetapkan, bahasa arti dari “ Janganlah kamu shalat dalam sehari dua kali" adalah apabila seseorang melaksanakan shalat

18 Ibid. 
fardhu, maka janganlah lagi ia mengulang shalat untuk kedua kalinya dengan niat melaksanakan shalat fardhu juga. Adapun mengulang shalat bersama jamaah atas nama sunat mengingat perintah Nabi SAW itu tidaklah dipandang mengulangi suatu fardhu dalam sehari dua kali; karena yang pertama dihukum fardhu, sedang yang kedua dihukum nafilah( sunat). Tegasnya bukan mengulang shalat fardhu dua kali. ${ }^{19}$

Dalam kitab Syarah Sunan al-Tirmidzi di katakan bahwa maksud dari "janganlah kamu mengulang shalat dalam sehari dua kali" adalah larangan shalat atas dasar penetapan cakupannya yang meliputi pengulangan suatu shalat fardhu tanpa membedakan dalam pengulangan itu denga niat fardhu atau sunnah. ${ }^{20}$

Sedangkan dalam Subul al-Salam dijelaskan bahwa maksud dari "janganlah kamu mengulang shalat dalam sehari dua kali" adalah larangan untuk dua macam shalat dengan menganggap bahwa kedua- duanya adalah fardhu, bukan berdasarkan anggapan bahwa salah satunya adalah sunat (nafilah). Atau maksud hadis tersebut adalah larangan untuk melakukan shalat sendirian dua kali untuk shalat yang sama. ${ }^{21}$

Dalam kitab Raudhath al-Thalibin dijelaskan, ada beberapa pendapat mengenai mengulang shalat dengan berjamaah, di antaranya:

Jika seseorang telah mengerjakan shalat berjamaah dan kemudian dia mendapatkan jamaah yang lainnya, maka menurut pendapat abshah di sisi jumhur ulama dan mazhab alSyafi'i, dia juga disunnahkan untuk mengulanginya seperti jika dia telah mengerjakan shalat sendiri.

Tidak di-sunnah-kan untuk mengulangi shalat tersebut, berdasarkan hal ini di-makhrub-

\footnotetext{
19 Ibid.

20 Al-Mubarakfuri, op. cit., h. 441.

${ }^{21}$ Imam Muhammad Ismail al-Kahlani, op. cit.,
}

kan mengulangi shalat shubuh dan Ashar, tidak makhruh selain keduanya.

Apabila berjamaah itu lebih bertambah keutamaannya, seperti jika imam pada jamaah pertama lebih alim atau wara', atau jamaahnya lebih banyak atau berada pada tempat yang lebih mulia, maka disunnahkan untuk mengulangi shalatnya tersebut. Apabila tidak seperti dalam keadaan tersebut, maka tidak disunnahkan.

Di-sunnah-kan mengulangi shalatnya, selain Subuh dan Ashar. Jika kita mensunnahkan mengulangi shalat bagi orang yang shalat dalam keadaan sendirian maupun berjamaah, maka tentang mana kefardhuan yang telah dilaksanakannya itu ada dua pendapat: Qaul Jadid mengatakan bahwa yang menjadi shalat fardhu adalah shalat yang pertama dan yang shalat yang kedua menjadi sunnah., sedangkan qaul qadim mengatakan bahwa jika dia shalat sendirian, maka yang menjadi fardhu adalah shalat yang kedua. ${ }^{22}$

Untuk memahami hadis-hadis mukbtalif ini, ada beberapa metode penyelesaian yang ditawarkan oleh ulama hadis. Menurut penulis, metode penyelesaian hadis mukhtalif yang digunakan dalam memahami hadis ini adalah metode al-Jam'u wa al-Taufiq (penyelesaian dalam bentuk kompromi). Maksudnya adalah penyelesaian hadis-hadis mukbtalif dari pertentangan yang tampak (makna lahiriahmya) dengan cara menelusuri titik temu kandungan makna masing- masingnya sehingga maksud sebenarnya yang dituju oleh yang satu dengan yang lainnya dapat dikompromikan. Atau dengan perkataan lain, dengan cara mencari pemahaman yang tepat terhadap hadis-hadis yang tampak saling bertentangan tersebut yang menunjukkan kesejalanan atau kesalingketerkaitan makna

22 Imam Abu Zakariya bin Yahya bin Syaraf an Nawawi al- Dimasqi, Raudhath al Thalibin, Penerjemah Muhyidin, Abdurrahman Siregar, Moh Abididin Zuhri,( Jakarta: Pustaka Azzam, 2007), jilid 1. H. 697-798. 
yang dikandungnya sehingga masingmasingnya dapat diamalkan sesuai tuntunannya.

Bentuk pengompromiannya adalah melalui pendekatan "tematis korelatif", yaitu mencari titik temu dan memperhatikan keterkaitan makna satu dengan yang lainnya, agar maksud atau kandungan makna yang sebenarnya dari hadis-hadis tersebut dapat dipahami dengan baik dan dengan demikian pertentangan yang tampak dapat ditemukan pengompromiannya.

Dalam hadis dari Yazid terdapat kebolehan mengulang shalat dengan berjamaah, sedangkan dalam hadis dari Ibn Umar terdapat larangan mengulang shalat dalam menggunakan lafaz 'am yang menunjukkan larangan mengulang shalat baik shalat sebelumnya dilakukan seorang diri maupun dengan berjamaah. Jika diperhatikan pemahaman hadis secara utuh, maka sesungguhnya tidak ada pertentangan antara dua hadis di atas.

Hadis dari Yazid bin al-Aswad membolehkan mengulang shalat dengan ketentuan bahwa shalat yang diulang itu dilakukan atas nama shalat sunnah. Karena demikianlah pemahaman terhadap teks hadis. Sedangkan hadis dari Ibn Umar "Janganlah kamu shalat dalam sehari dua kali" maksudnya adalah apabila seseorang melaksanakan shalat fardhu, maka janganlah ia mengulang shalat untuk kedua kalinya atas nama shalat fardhu juga. Adapun mengulang shalat bersama jamaah atas nama sunnah mengingat perintah Nabi SAW agar mendapatkan fadhilah jamaah, tidaklah dipandang mengulangi shalat fardhu dua kali dalam sehari, karena shalat yang pertama dihukum fardhu, sedang shalat yang kedua dihukum nafilah (sunat). Dalam hal ini, niat shalat yang diulang tetap sama seperti niat shalat fardhu, akan tetapi pahala bagi orang yang mengulang shalat itu dihukum menjadi ibadah sunnah baginya.

\section{HUKUM MENGULANG DENGAN BERJAMA'AH}

Ada beberapa persoalan yang muncul terkait dengan hadis-hadis yang membolehkan dan hadis-hadis yang melarang mengulang shalat dengan berjamaah. Berikut ini tabel yang berisi identifikasi persoalan mengulang shalat dengan berjamaah.

\section{Hadis yang membolehkan mengulang shalat dengan berjamaah.}

Mengenai hukum shalat yang telah diulang. Pendapat dari al Hasan, al- Zuhri, Imam al-Syafi'i, Imam Ahmad dan Imam Ishaq bahwa shalat yang diulang menjadi shalat sunnah. Pendapat dari al-Auza'i dan qaul qadim al-Syafi'i bahwa shalat yang diulang menjadi shalat fardhu.

Waktu shalat yang dapat diulang. Imam al-Syafi'i berpendapat bahwa mengulang shalat boleh dikerjakan pada semua waktu shalat. Pendapat dari Imam Malik dan pengikutnya adalah mengecualikan waktu shalat Maghrib. Pendapat dari Imam Malik dan Abu Hanifah adalah mengecualikan waktu shalat Subuh, Maghrib dan Ashar.

Mengulang shalat tapi sebelumnya ia telah shalat berjamaah. pendapat Imam Malik, Al-Syafi'i dan Abu Hanifah adalah tidak boleh mengulang shalat jika sebelumnya telah shalat berjamaah. Imam Ahmad, Abi Dawud dan kelompok zhahir membolehkan mengulang shalat tersebut.

Hadis yang melarang mengulang shalat dengan berjamaah

Hadis ini secara lahir tampak bertentangan dengan hadis yang pertama, sehingga perlu metode penyelesaian yang tepat dalam memahaminya. Berdasarkan syarah hadis yang terdapat dalam beberapa kitab, seperti subul alssalam, tuhfath al-ahwadzi, dan lain-lain dapat terlihat bahwa ulama menggunakan metode pemahaman al-jam'u wa al-tawfiq, dengan 
memakai pendekatan tematis korelatif, sehingga diperoleh pemahaman bahwa dibolehkan mengulang shalat untuk kedua kalinya secara berjamaah dengan ketentuan shalat yang diulang dihukum menjadi menjadi shalat sunnah.

Persoalan yang pertama adalah bagaimana hukum dari shalat yang diulang dengan berjamaah. Dalam hal ini, ada dua pendapat ulama, yaitu:

Pertama, Pendapat dari al Hasan, alZuhri, Imam al-Syafi'i, Imam Ahmad dan Imam Ishaq bahwa siapa yang telah selesai shalat, lalu menghadiri shalat berjamaah dengan yang lain, maka shalat yang pertama adalah shalat fardhu sedangkan shalat yang kedua adalah shalat sunnah. Dalil yang mereka kemukakan adalah hadis riwayat Yazid bin alAswad

Kedua, Al- Auza'i dan sebagian sahabat al-Syafi'i berpendapat, yaitu pendapat lama alSyafi'i (saat masih di Baghdad), bahwa shalat yang dihukumi fardhu adalah shalat yang kedua, jika shalat yang pertama dilakukan sendirian. Dalil yang dikemukakan adalah hadis riwayat Yazid bin 'Amir

Berdasarkan takbrij yang telah penulis lakukan sebelumnya, serta informasi-informasi yang diperoleh dari berbagai kitab syarah hadis, diketahui bahwa dalil yang dikemukakan oleh al-Auza'iy dan qaul qadim al-Syafi'i itu sangat lemah karena kualitas hadis dari Yazid bin Amir adalah hadis dha'if, jadi tidak dapat dijadikan sebagai hujjah dan tertolak (mardud). Maka dapat disimpulkan bahwa hukum shalat yang diulang dengan berjamaah itu adalah sunnah (nafilab)

Persoalan kedua, mengenai waktu shalat yang dapat diulang. Dalam hal ini ada tiga pendapat.

Pertama, Pendapat dari Imam Malik dan pengikutnya : Jika ia sudah melaksanakan shalat sendirian, ia harus mengulangi shalat dengan berjamaah, kecuali untuk shalat Maghrib. Alasan pengecualian untuk shalat
Maghrib karena bilangan shalat Maghrib itu adalah ganjil, lalu jika diulangi maka akan menjadi genap, yaitu enam rakaat, dengan demikian satu jenis shalat berpindah pada jenis yang lainnya. Imam Malik memahami hadis 'am ini dengan men-takbshsish-nya dengan qiyas syibih.

Kedua, Pendapat Abu Hanifah, hendaknya ia mengulangi semuanya kecuali shalat Subuh, shalat Maghrib dan Ashar. Tidak dibolehkan mengulang pada shalat Subuh dan Ashar karena di-makhruh-kan menunaikan shalat pada waktu itu. Adapun tidak dibolehkan pada shalat Maghrib karena shalat Maghrib termasuk shalat ganjil, kalau diulangi akan menjadi genap.

Ketiga, Pendapat Imam al-Syafi'iy, mengulang shalat dapat dilakukan pada semua waktu shalat, ia tidak mengecualikan shalat apapun. Imam al-Syafi'i memahami hadis dengan memahami makna 'am nya.

Dalam hal ini, penulis berpendapat bahwa pengecualian waktu shalat Subuh itu bertentangan dengan lafal teks hadis, di mana latar historis kejadian hadis itu adalah setelah shalat Subuh di mesjid Khaif. Walaupun ada dalil lain yang me-makhrub-kan shalat setelah shalat Subuh, namun hadis dari Yazid bin alAswad itu men-takhshish-nya. Demikian juga dengan pengecualian waktu shalat Maghrib dengan alasan, bahwa mengulang shalat Maghrib didasarkan pada takhshsish hadis 'am dengan qiyas syibih, karena bilangan shalat Maghrib itu adalah ganjil, lalu jika diulangi maka akan menjadi genap, yaitu enam rakaat, dengan demikian satu jenis shalat berpindah pada jenis yang lainnya. Namun qiyas di atas sangat lemah, karena " salam" telah mengakhiri suatu shalat dan memisahkan antara berbagai shalat ganjil tersebut, sementara memegang teguh yang umum lebih kuat dari pada menjadikan qiyas seperti ini sebagai dasar pengecualingan. Oleh karena itu, menurut penulis pengulangan shalat dapat dilakukan pada semua waktu shalat, walaupun 
dalam teks hadis kejadian itu khusus pada shalat Subuh, namun sesuai dengan kaedah ushul dalam memahami hadis, al 'ibrah bi umum al fazh la bi khushubs al-sabab, jadi walaupun teks hadis menceritakan hanya pada waktu shalat Subuh, namun dapat juga dilakukan untuk semua waktu shalat, dengan memperhatikan aspek ám hadis tersebut.

Persoalan ketiga, apakah mengulang shalat itu dapat dilakukan jika sebelumnya telah melakukan shalat jamaah atau hanya dapat dilakukan jika sebelumnya shalat sendirian. Mengenai hal ini, ada dua pendapat:

Pertama, pendapat dari Malik, Abu Hanifah, al-Syafi'i dan sahabat-sahabat mereka. Adapun orang yang dianjurkan mengulang shalat bersama imam dengan berjamaah hanya orang yang shalat sendirian di rumahnya atau di luar rumahnya. Sedangkan orang yang shalat dalam suatu jamaah meskipun sedikit, maka ia tidak dianjurkan mengulanginya pada jamaah yang lebih banyak. Karena , jika ia di anjurkan untuk mengulanginya pada jamaah yang lain, maka ia pun akan dianjurkan mengulanginya pada shalat yang ketiga dan keempat hingga tiada batas akhirnya dan kerusakannya tidak dapat diragukan lagi. Dalil mereka adalah hadis yang melarang mengulang shalat fardhu (yang sama) dua kali dalam satu hari. Bagaimanapun jika orang yang telah shalat berjamaah lalu menjumpai jamaah lagi, maka ia tidak boleh mengulang shalatnya lagi, bagaimana pun keadaannya, karena tujuan mengulangi adalah mendapat fadhilah jamaah, padahal fadhilah itu sudah didapatkan sebelumnya.

Kedua, menurut Ahmad, Daud, dan Kelompok Zhahir, berpendapat bahwa shalat itu diulang, walaupun sebelumnya mereka telah shalat dengan berjamah. Alasannya adalah hadis dari Yazid bin al-Aswad. Dalam redaksi hadis terlihat jelas bahwa Nabi menyuruh untuk kembali shalat, walupun telah melaksanakan shalat sebelumnya. Zhahir hadis mengharuskan pengulangan shalat bagi seseorang yang datang ke Mesjid. Sebab, hadis ini mempunyai kekuatan sebagai dalil secara umum, kebanyakan ulama berpendapat bahwa jika dalil umum didatangkan dalam sebuah kasus yang khusus, maka dalil tersebut tidak dipahami sebatas permasalahan itu saja.

Penulis berpendapat bahwa pengulangan shalat dapat dilakukan jika sebelumnya telah melakukan shalat sendirian karena demikianlah isi teks hadis. Alasan lainnya adalah jika orang yang telah shalat berjamaah kemudian menjumpai jamaah lagi, maka ia tidak boleh mengulang shalatnya lagi.

\section{KESIMPULAN}

Setelah melakukan penelitian terhadap hadis-hadis tentang mengulang shalat dengan berjamaah, maka dapat disimpulkan bahwa dibolehkan bahkan dianjurkan bagi orang yang ingin mengulang kembali shalatnya dengan berjamaah, walaupun sebelumnya ia telah melakukan shalat sendirian.

Hukum shalat yang dilakukan kedua kalinya itu dapat menjadi shalat sunnah. Pengulangan shalat dapat dilakukan pada semua waktu shalat. Pengulangan shalat dapat dilakukan hanya jika sebelumnya telah melakukan shalat sendirian. Metode tepat yang digunakan dalam memahami hadis-hadis tentang mengulang shalat dengan berjamaah adalah memakai metode metode al-Jam'u wa alTawfiq (penyelesaian dalam bentuk kompromi) dengan pendekatan pemahaman tematis korelatif). 


\section{DAFTAR KEPUSTAKAAN}

Abdurrahman bin Abdurrahman al Mubarakfuri, Abu Alula Muhammad Tuhfath al-Ahwadriy Syarah Sunan al-Tirmidriy, Penerjemah Shafaul Qalbi, Jakarta: Pustaka Azzam, 2008

Abdurrahman bin Abi Hatim Muhammad bin Idris bin Mundziral Tamimy al-Hanzuly Abu Hatim, Imam Hafiz Syaikh Islam Abi Muhammad, Kitab al-Jarb Wa al-Ta'dil, Mesir : Dar al Kutub, 1953

Abi al-Hajaj Yusuf Bin Abdurrahman al-Mizzi, Imam al-Hafidz Jamaluddin Tahæib al-Kamal fi asmai al-Rijal, Dar al-Fikr, Beirut-Lebanon, 1414 H/ 1994 M

Abi Bakr Al-Suyuthi, Jalaluddin Abdurrahman, Al-jami' al-Shagiir fi Ahaadits al-Basyiir al-Naziiir, Indonesia : Maktabah Daar Ihya Al-Kutub Al- 'Arabiyyah, t. th.

Al-Dimasqi, Imam Abu Zakariya bin Yahya bin Syaraf an Nawawi Raudhath al-Thalibin, Penerjemah Muhyidin, Abdurrahman Siregar, Moh Abididin Zuhri, Jakarta: Pustaka Azzam, 2007

Al-Farmawi, Abd al-Hay. Al-Bidayah fi al-Tafsir al-Maudhu'iy t. tp. : Matba'ah al-Hadarah al'Arabiyyah. 1997

Al-Munawwir, Kamus al-Munawwir Arab-Indonesia Terlengkap, Surabaya: Pustaka Progresif, 1997

Buchari, Metode Pemahaman Hadis, Jakarta: Nuansa Madani, 1999

Edi Safri, Edi Al-Imam al-Syafi'i: Metode Penyelesaian Hadis-Hadis Mukhtalif, Padang, IAIN IB Press, 1999

Hanbal, Ahmad bin, Musnad Ahmad Bin Hanbal, Beirut: Dar al-Fikr, t. th.

Ibn Manzhur, Muhammad Ibn al Mukarran Lisan al-Arab al-Muhith, (Beirut: Dar Lisan al-Arab, t. th.

Khaeruman, Badri, Otentisitas Hadis, Bandung: PT Remaja Rosdakarya, 2004

Maizuddin, Metodologi Pemahaman Hadis Padang: Hayfa Press, 2000

Muhammad Ajaj al-Khatib, al-Sunnab Qabla al-Tadwin, al-Qahirah: Maktabah Wahbah, 1975

Salim, Peter, Kamus Besar Bahasa Indonesia Kontemporer, Jakarta: Moderen English Press, t. th.

Sabiq, Syeikh Sayyid, Fiqh Sunnah, Qahirah: Dar al-Fikri, 1365 
Sulaiman bin al-Ats'atsi al-Sajastani, Imam Hafiz Abi Dawud, Sunan Abi Dawud, Beirut : Dar alKutub al-'Alamiyah, 2005

Tim Penyusun Kamus Pusat Pembinaan dan Pengembangan Bahasa, Kamus Besar Bahasa Indonesia, Jakarta: Balai Pustaka, 2007

Wensink, Arnold. J. Mu'jam al-Mufaharas li Alfažb al-Hadits al-Nabawi, Leiden, E.J, Brill, 1969

Yunus, Mahmud. Kamus Arab-Indonesia. Jakarta: Yayasan Penyelenggara Penterjemah Penafsir AlQur'an. 1973

Zulhedi, Hadis- Hadis yang Bertentangan, Jakarta: Nuansa Madani, 2001 